\title{
A "ilusão da catequese": interfaces entre o discurso intelectual e católico na Bahia do século XIX na produção de um conhecimento sobre as religiosidades afro-brasileiras
}

The "illusion of catechesis": interfaces between intellectual discourse and Catholic discourse in Nineteenth Century Bahia, in knowledge production about the AfricanBrazilian religiosity

La "ilusión de la catequesis": las interfaces entre el discurso intelectual y católico en Bahia del siglo XIX en la producción de conocimientos sobre la religiosidad afro-brasileña

Vanda Fortuna Serafim ${ }^{*}$

\section{Resumo}

O objetivo deste trabalho consiste em perceber as interpretações elaboradas sobre a religiosidade baiana, tomando como fontes históricas as obras $O$ animismo fetichista dos negros bahianos (1935) e Os africanos no Brasil (1982), de Nina Rodrigues; e as Constituições Primeiras do Arcebispado da Bahia, de autoria do arcebispo D. Sebastião Monteiro da Vide, promulgadas em 1777. Mais especificamente, perceber como esta poderia ter contribuído para a elaboração da noção de "ilusão da catequese" presente em Nina Rodrigues para produzir um conhecimento acerca das religiosidades afro-brasileiras, na Bahia do século XIX. Os aportes teóricos utilizados consistem em Michel de Certeau (1982) para pen- sar a antropologia da crença e "formalidades das práticas" católicas; e em Roger Chartier $(1990,2002)$ e os conceitos de "visão de mundo" e "representação".

Palavras-chave: Ilusão da catequese. Nina Rodrigues. Religiosidade baiana.

\footnotetext{
Doutora em História pela Universidade Federal de Santa Catarina, professora adjunta na Universidade Estadual de Maringá e docente do Programa de Pós-Graduação em História (PPH-UEM). Atua como pesquisadora/docente do Núcleo de Pesquisa em História Religiosa e das Religiões (CNPQ) e no grupo de trabalho em História das Religiões e das Religiosidades (ANPUH). É editora da Revista Brasileira de História das Religiões.
}

Recebido em 08/08/2013 Aprovado em 21/09/2013 http://dx.doi.org/10.5335/hdtv.14n.1.3388 
A proposta deste artigo surgiu após apresentar uma comunicação no XXVII Simpósio Nacional de História - Conhecimento Histórico e Diálogo Social (ANPUH), ao participar de um simpósio temático voltado para as religiões mediúnicas e afro-brasileiras no âmbito da pesquisa histórica, no qual iniciei uma reflexão sobre os discursos produzidos sobre religiosidade na Bahia dos séculos XVIII e XIX. Ao tomar por base os escritos do Arcebispo D. Sebastião Monteiro da Vide (1643 - 1722) e do médico Raimundo Nina Rodrigues (1862-1906), busquei contribuir com a percepção dos trabalhos de Nina Rodrigues enquanto um esforço intelectual e católico no que tange aos estudos das religiões e religiosidades afro-brasileiras.

Ao partir da compreensão da religiosidade baiana do século XIX, objetivei comparar como essa teria sido representada no discurso de dois intelectuais: um arcebispo e um médico. Para tanto, tomei como fontes históricas as obras $O$ animismo fetichista dos negros bahianos e Os africanos no Brasil, com publicações originais de 1900 e 1932, mas escritas entre 1890 e 1905 por Nina Rodrigues; e as Constituições Primeiras do Arcebispado da Bahia, de autoria do arcebispo D. Sebastião Monteiro da Vide, promulgadas em 1777.

Dentre os aportes teóricos e metodológicos utilizados para essa reflexão, destacamos: Michel de Certeau e a obra A escrita da história (1982) para pensar a antropologia da crença e "formalidades das práticas" católicas na construção de um discurso que elas já não mais determinariam, juntamente com Roger Chartier (1990, 2002) e os conceitos de "apropriação", "visão de mundo" e "representação", os quais nos permitem comparar as formas como as obras analisadas interpretam a realidade social de seu contexto histórico, e mais diretamente como propõem um entendimento da atuação da religião na Bahia.

$O$ interesse em analisar as obras de Monteiro da Vide e Nina Rodrigues é consequência da inquietação causada ao estudar as obras $O$ animismo fetichista dos negros bahianos (1935) e Os africanos no Brasil (1982), e constatar que, a todo o momento, Nina Rodrigues refere-se a um "catolicismo ideal", que seria pouco compreendido e ainda menos praticado pela população baiana de fins do século XIX. Esse catolicismo seria livre de "fetichismos", "idolatrias", apego à materialidade, crenças tidas como próprias do senso comum, dos santos diversos, das músicas, das danças e das festividades. E, mais que isso, seria alcançado apenas em longo prazo, com a evolução cultural dos povos que habitavam o Brasil (RODRIGUES, 1935, 1982). Convém ressaltar, a crítica pela não evolução não era feita unicamente aos africanos e seus mestiços, mas aos brancos também; não apenas à população baiana em geral, mas aos clérigos e detentores de importantes cargos sociais: advogados, médicos e políticos.

Para Nina Rodrigues (1935), era evidente a não conversão dos "áfrico-bahianos" ao catolicismo. Ele afirmou ainda que apenas uma ciência oficial, superficial e dogmática, presa às exterioridades e aparências não verificadas, afirmaria que a população baiana em fins do século XIX era em sua totalidade monoteísta cristã católica. O animismo fetichista dos negros bahianos constitui o esforço empírico de Nina Rodrigues em investigar o sentimento religioso dos africanos e seus 
descendentes, para além do que considerava enquanto exterioridade do culto.

Lembrando que esse autor, como boa parte da ciência médica do XIX, operava o termo "raça", ele consegue - ainda que com o intuito de demonstrar como o pensamento da "raça negra", tida como inferior, não poderia ser forçosamente colocado no mesmo patamar da "raça branca", tida como superior - demonstrar, mesmo que não propositalmente, todo o esforço de resistência do africano em um mundo tão diferente do seu. Mostra-nos como os africanos, ao invés de convertidos, teriam convertido os brancos católicos às suas práticas. No entendimento ainda desse autor, seria ilusório afirmar que os negros baianos eram católicos e que a tentativa de conversão católica teve êxito. Ao invés de converter o negro ao catolicismo, o branco teria sido influenciado pelo negro, adaptando-se ao "animismo rudimentar", buscando uma assimilação.

A conversão teria sido exterior às crenças e práticas fetichistas, que em nada teriam se modificado. Porém, pondera Nina Rodrigues (1935) que, embasando o entendimento de seu pensamento enquanto evolucionista, como as leis de evolução seriam as mesmas em todas as raças, essa fusão faria com que o negro chegasse à capacidade mental necessária para compreender o monoteísmo católico. Todavia, essa não seria a forma como estaria organizada a religiosidade na sociedade baiana, pelo contrário, o que se verificava era a nítida influência fetichista nas demais religiões. De acordo com o autor, todas as crenças e práticas recebiam e refletiam por igual o influxo da feitiçaria e da idolatria do negro.
Nesse sentido, a fim de compreender a organização social na Bahia, foram criadas condições para que se desenvolvesse o pensamento de Nina Rodrigues acerca das religiões. Nesse sentido, compreendo como esclarecedor à compreensão das críticas, dos desabafos, dos depoimentos e das considerações realizadas por esse autor, atentarmos ao que pode ser considerado "um verdadeiro espelho do ideal de funcionamento do aparelho religioso e da sociedade católica" da Bahia (FEITLER et al., 2010, p. 07).

Refiro-me às Constituições Primeiras do Arcebispado da Bahia, de autoria do arcebispo D. Sebastião Monteiro da Vide, promulgadas em 1777, e que se constitui como um trabalho de adaptação das normas eclesiásticas à realidade local de uma diocese luso-americana. As constituições permaneceram em vigor, com algumas modificações, até o fim do Império, "longevidade atestadora de seu êxito e indicativa de sua grande importância enquanto fonte para o estudo da Igreja e da sociedade brasileiras" (FEITLER et al., 2010, p. 07). E acrescenta, das motivações que levaram Nina Rodrigues a atribuir à prática católica da Bahia o predicativo de "ilusões da catequese" e a acusação de que, ao invés de converterem os negros africanos, os padres eram convertidos por eles. ${ }^{1}$

Há de se considerar que Nina Rodrigues possuía formação católica, foi batizado, crismado e cursou as séries iniciais no Seminário das Mercês, em São Luís do Maranhão. $\mathrm{Na}$ Bahia, casou-se na Igreja e batizou sua única filha. Nina Rodrigues vivenciava o catolicismo brasileiro, especialmente o baiano. A comparação de seus escritos ao teor discursivo das constituições permite compreender, 
por um lado, as críticas lançadas à adaptabilidade do Catolicismo baiano, sempre festivo e maleável (em alguns casos preferíveis a certas práticas africanas híbridas com o Islã, por conta da rigidez das regras, como foi o caso Malê); e, por outro lado, permite estabelecermos o modelo de religião do qual Nina Rodrigues aproximava-se ou distanciava-se, uma vez que era o que conhecia. ${ }^{2}$

$\mathrm{O}$ exame de algumas das principais ações de Monteiro da Vide, descrito como de "relativa tolerância devocional" (FEITLER et al., 2010, p. 17), enquanto arcebispo da Bahia, não deixa dúvidas quanto ao seu caráter de prelado zeloso, em particular no que diz respeito a dotar a igreja luso-americana de legislação própria. Aspecto esse merecedor das críticas de Nina Rodrigues, afinal, como contribuir à evolução das "raças" presentes no Brasil, se aquelas que teriam condições de auxiliam a ascender, estariam, ao invés disso, nivelando-se ao parâmetro das capacidades intelectuais das ditas "raças inferiores"?

O número de brancos, mulatos e indivíduos de todas as cores e matizes que vão consultar os negros feiticeiros nas suas aflições, nas suas desgraças, nos que crêem publicamente no poder sobrenatural dos talismans e feitiços, dos que em muito maior numero, zombam deles em publico, mas occultamente os ouvem, os consultam, esse numero seria incalculável se não fosse mais simples dizer de um modo geral que é a população em massa, a excepção de uma pequena minoria de espíritos superiores e esclarecidos que tem a noção verdadeira do valor exacto dessas manifestações psycologicas. É que no Brazil o mestiçamento não é só physico e intellectual, é ainda affectivo ou dos sentimentos, religioso igualmente portanto (RODRIGUES, 1935, p. 186).
É interessante perceber as diferentes preocupações entre ambos. Nina Rodrigues, por um lado, ao partir do pensamento evolucionista, defendia que à medida que as "raças" entendidas como mais "evoluídas" se desenvolvessem, auxiliariam, mesmo que lentamente, o desenvolvimento das ditas "raças inferiores"; assim, nesse sentido, ao indicar o catolicismo enquanto religião das "raças evoluídas", é necessário garantir que esse não se contamine com os "fetichismos" e as "idolatrias" das crenças e religiosidades afro-brasileiras, próprias das "raças inferiores". Por outro lado, preocupado em não "esfriar a devoção" na Bahia, a atitude de Monteiro da Vide sugere ser reveladora da opção por um método de conversão marcado pela busca, sobretudo, em atrair os fiéis para a Igreja, tolerando, se preciso, alguns desvios. Nesse caso, o arcebispo estaria entre aqueles que pensavam não ser factível a adoção de uma política mais rigorosa de enquadramento religioso antes da sedimentação da fé cristã numa comunidade formada majoritariamente por "recém-conversos". O arcebispo era também um incentivador ao culto aos santos, em particular o culto mariano. O modelo de santidade concebido por Monteiro da Vide parece ser aqueles ligados à construção da santidade barroca: vida penitente, fervorosa oração e luta contra o satanás. Ao escrever a vida de Vitória da Encarnação, ele deixa transparecer sua própria concepção sobre santidade, revelando, assim, alguns traços de sua piedade. Atos de rigorosa penitência e mortificação da carne eram entendidos como estimulantes à conversão de pecadores. A percepção de que não há santidade sem dor é marcante 
em Monteiro da Vide. Não há como negar a força que parece desfrutar o dolorismo entre os séculos XVI e XVII - mantendo-se ainda vigoroso durante boa parte do século XVIII - apresentando-se como um traço de união entre os homens e diferentes sensibilidades religiosas (FEITLER et al., 2010).

A descrição sobre a postura de Monteiro da Vide, que parece ter sido assumida de forma ainda amais aberta pelas hierarquias religiosas baianas, corrobora com as descrições que encontramos em Nina Rodrigues acerca da formação religiosa na Bahia. Como o catolicismo era atrativo aos africanos e seus mestiços, principalmente por conta dos santos, que se confundia com a ideia de politeísmo católico. As formas festivas assumidas pelo culto católico no Brasil lembravam os excessos das celebrações africanas, e, consequentemente, a falta da autoridade clerical mediante os recém-conversos.

$\mathrm{O}$ animismo fetichista africano, diluído no fundo supersticioso da raça branca e reforçado pelo animismo incipiente do aborigene americano, constitui o subsolo ubérrimo de que brotam exuberantes todas as manifestações ocultistas e religiosas da nossa população. As crenças catholicas, as práticas espíritas, a cartomancia, etc., todas recebem e reflectem por igual o influxo da feitiçaria e da idolatria fetichista do negro (RODRIGUES, 1935, p. 167).

Rodrigues começa a esboçar timidamente, na obra acima, o que viria a desenvolver em Os africanos no Brasil: uma sociedade baiana cercada de "sobrevivências fetichistas", a qual acreditava em mesas girantes, bênçãos e palavras mágicas. Esse seria o universo baiano presenciado e testemunhado por Nina Rodrigues, um emaranhado de crenças diversas, em que se hibridizavam ideias católicas, espíritas, "maometanas", fetichistas e as mais diversas práticas mágicas. Ao invés do negro converter-se ao catolicismo, esse seria influenciado pelo fetichismo e acabava adaptando-se ao animismo rudimentar de modo a torná-lo assimilável. A forma como a conversão ocorria para os negros africanos existentes no Brasil e em seus descendentes teria sido apenas exterior:

Concebem os seus santos ou orisás e os santos catholicos como categoria igual, embora perfeitamente distinctos. Abrigados na ignorância geral da língua que elles falam e na facilidade com que. Para condescender com os senhores, os africanos escravizados se declaravam e apparentavam convertidos ao catholicismo, as práticas fetichistas puderam manter-se entre elles até hoje quase tão extreme de mescla como na África (RODRIGUES, 1935, p. 168-169).

O que para Nina Rodrigues teria facilitado o processo de assimilação foi a presença de objetos no culto católico, como altares e imagens de santo. $\mathrm{O}$ autor, ainda, vai além, ao conjecturar que o negro africano estava ciente todo tempo do que ocorria, percebia aquele objeto como um fetiche e associava-o ao uso e à interpretação que comumente fazia-se deles. Apenas o branco ou o padre jesuíta, protegido em sua pretensão de conversão, poderia acreditar que o fato do negro cultuar/adorar uma imagem, o tornaria um modelo exímio de católico. Iniciar-se-ia assim, a degeneração do fetichismo primitivo, por parte do negro crioulo e do mestiço que não foram diretamente educados pelo africano: 
[...] as práticas fetichistas e a mytologia africana vão degenerando da sua pureza primitiva, gradualmente sendo esquecidas e abastardas, ao mesmo tempo que se transfere para os santos catholicos a adoração fetichista de que eram objetos os orisás (RODRIGUES, 1935, p. 170).

Descrito pelos organizadores da obra como um indivíduo que viveu as contradições de seu tempo, Monteiro da Vide foi um homem da Igreja que manifestou a sensibilidade religiosa em uma época em que o "desencantamento" ainda não havia tocado fundo a alma humana e a própria Igreja (FEITLER. et al., 2010). Nesse sentido, é possível aproximá-lo de Nina Rodrigues, na medida em que ambos cumprem em seus escritos uma dupla função: a de intelectual e a de católico, embora a ordem de importância não seja a mesma para ambos.

Pensando nas discussões e inquietações presentes em Nina Rodrigues acerca do caráter imanente ou transcendente dos fetiches, não parecem ser suficientes as repostas católicas dadas no Livro Primeiro das Constituições quanto à "adoração que se deve a Deus Nosso Senhor, à Virgem Maria Nossa Senhora e aos santos" e ao "culto devido às santas relíquias e sagradas imagens".

Latria é a adoração devida somente a Deus Nosso senhor, e é um ato de religião radicado na alma, com o qual devemos reconhecer sua divina excelência, prostrando-nos de joelhos em terra com a cabeça descoberta e mãos juntas e levantadas, batendo nos peitos e fazendo outros atos exteriores de veneração que correspondam aos cultos de nossos corações, reconhecendo-o por Deus e supremo Senhor [...]. Hiperdulia é outra veneração com o que somos obrigados a venerar a Virgem Maria Nossa Senhora, por ser mãe de Jesus Cristo Nosso Salvador, e conter em si todas as virtudes. Esta adoração se faz descobrindo a cabeça e fazendo-se oração com joelhos em terra. Dulia é outra veneração, que se faz rezando em pé ou de joelhos com a cabeça descoberta; e é de fé que os anjos e espíritos celestiais e santos, aprovados por tais pela Igreja, com ela devem ser venerados [...] (VIDE, 2010, p. 134). ${ }^{3}$

A descrição acima, por um lado, parece demonstrar o sistema complexo intelectual, com as elevadas abstrações monoteístas que Nina Rodrigues esperava, e, por outro, denunciam a ritualística suspeita de um catolicismo monoteísta com muitos deuses e que em muito aproximava-se da idolatria fetichista, precisando ainda, por meio da evolução, perder essas características materialistas voltadas à exterioridade do culto. A crítica do documento é importante também para percebermos que a necessidade de um conjunto de orientações, com penas e castigos espirituais, que orienta que a adoração das imagens se dê não porque nelas habitam uma divindade, mas pelo que elas representam, era resultado e resposta a uma prática constante, que iria, justamente, contra essas orientações. No entendimento de Nina Rodrigues, a forma como a conversão teria ocorrido para os negros africanos existentes no Brasil e em seus descendentes teria sido apenas exterior:

Concebem os seus santos ou orisás e os santos catholicos como categoria igual, embora perfeitamente distinctos. Abrigados na ignorância geral da língua que elles falam e na facilidade com que. Para condescender com os senhores, os africanos escravizados se declaravam e apparentavam convertidos ao catholicismo, as práticas fetichistas puderam manter-se entre elles até hoje quase tão extreme de mescla como na África (RODRIGUES, 1935, p. 168-169). 
A "prática fetichista católica" baiana seria mais evidente mediante a ritualística de seu culto, descrita por Nina Rodrigues como "pomposa". As orientações sobre o uso dos óleos são pensadas como exemplo disso. É difícil não conjecturar as possíveis associações ritualísticas, feitas por Nina Rodrigues, entre catolicismo e religiões afrodescendentes ao deparar-se com as normatizações e as orientações contidas nas Constituições acerca das santas imagens, no sentido de que a imagem da cruz não deveria ser pintada nem levantada em lugares indecentes; bem como sobre os procedimentos para a reforma das imagens envelhecidas; sobre como agir com ornamentos, móveis, altares e vasos das Igrejas; o que se fazer com os ornamentos velhos, com a madeira, com as pedras e com as telhas retiradas das Igrejas. As orientações contemplavam, ainda, a reverência devida a igrejas e lugares sagrados, que devem ter contribuído, também, para a construção do pensamento intelectual de Nina Rodrigues, que entende que a religião monoteísta no Brasil ainda não alcançou seu auge, especialmente na Bahia, onde estaria envolta de fetichismos.

Outro ponto refere-se à questão do sacrifício. Vide pronuncia-se sobre "o santo sacrifício da missa: sua instituição, frutos e efeitos", orientando que esse seria "o verdadeiro, o real e o único sacrifício que tem a Igreja Católica, porque o mesmo Cristo que institui como verdadeiro o mistério do seu corpo e sangue sacramentado quis que o mesmo mistério fosse verdadeiro sacrifício" (2010, p. 267). Esse é um ponto extremamente interessante em se saber o pronunciamento de Nina Rodrigues, todavia, em momento algum ele se pronuncia em defesa ou acusação do dogma, detém-se apenas em informar que faria parte de uma forma de religiosidade mais complexa, de elevadas abstrações e de difícil compreensão àqueles das raças inferiores.

Há, portanto, em Nina Rodrigues, uma postura de não questionamento dos dogmas católicos. O que se questiona são as posturas clericais e os usos sociais feitos desses dogmas. Nina Rodrigues não ataca o sentimento religioso, mas a manipulação desse por aqueles que estariam dispostos a aproveitarem-se das ditas mentes incrédulas. Isso torna-se mais evidente, por exemplo, quando os padres começam a agir no campo da cura de doenças.

A preocupação com as doenças de alma são rechaçadas, por Nina Rodrigues, como "sobrevivências primitivas" que assolam os diferentes níveis sociais da cultura baiana do XIX, as quais também podem ser detectadas entre as orientações de Monteiro da Vide, especialmente em "Como os médicos e cirurgiões devem admoestar aos doentes que se confessem e comunguem" (2010, p. 198), O Arcebispo indica que, muitas vezes, a enfermidade do corpo estaria na alma enferma com o pecado. Assim, a orientação era para antes de aplicar a medicina para o corpo, tratassem primeiro da medicina da alma.

Esse tipo de procedimento, na visão de Nina Rodrigues, por parte do clero português, contribuiria para avivar o espírito curandeiro existente entre os africanos e seus descendentes, e ocasionaria, ainda, que, em muitas vezes, mesmo a dita sociedade branca e esclarecida, criada dentro da fé católica, busca os cuidados de benzedeiras, 
curandeiros, entre outros "charlatães", em detrimento dos médicos profissionais. É visível então, a defesa e a busca de um estatuto para a medicina no século XIX.

A postura anticlerical de Nina Rodrigues, a ponto de defender pais e mães de santo em detrimento dos padres, dá-se, por vezes, sob a argumentação de que a acusação de abuso sexual e de vida desregrada feita aos primeiros valeria também aos clérigos. São, nesse sentido, exemplar e passíveis de crítica histórica as orientações feitas pelo arcebispo aos clérigos baianos no "Livro Terceiro" a respeito da "obrigação que tem os clérigos de viver virtuosa e exemplarmente", "Dos vestidos que os clérigos poderão usar e dos que lhe são proibidos", "Como os clérigos não podem comer nem beber em tavernas, nem ir a boates ilícitas", "Como os clérigos não podem entrar em comédias ou danças, nem em festas de cavalo, nem disfarçar-se com máscaras", "Como os clérigos não devem jogar jogos proibidos, nem dar casas de jogos", "Em que se obriga aos clérigos que não usem de trato e mercancia, nem façam fianças por ganhos e interesses", "Em que se ordena que os clérigos não possam ter de porta adentro mulheres em que possa haver suspeita, nem frequentar o mosteiro de freiras" (VIDE, 2010, p. 311-322). Retornando à ideia apresentada, de que as orientações dadas pelo arcebispo não se pautariam em práticas não inexistentes, tornam-se assimiláveis as afirmações e críticas de Nina Rodrigues.

É possível perceber, ainda, que a preocupação com jogos, bebidas e festas, enquanto elementos profanos e que degradariam a imagem da Igreja; assim como a leitura intelectual dessas práticas enquanto sobrevivências de uma idade primitiva, caracterizam a postura intelectual e católica em Nina Rodrigues.

Assim, encontramos as orientações de Monteiro da Vide (2010) determinando que nas Igrejas não se façam farsas e jogos profanos, nem se coma, beba, durma, baile ou façam novenas:

Pelos inconvenientes que resultam de que as Igrejas, feitas para louvores de Deus e exercícios de espírito, sirvam de nelas se comer, se beber e fazer outras ações muito indecentes ao tal lugar, de que nascem mil descomposturas indignas dele, conformando-nos com disposição de direito, sagrado Concílio Tridentino, e constituição do Santo Papa Pio V, ordenamos e mandamos, sob pena de excomunhão e dez cruzados, que nenhuma pessoa eclesiásticas ou seculares tanjam ou bailem, nem façam danças ou jogos profanos nas igrejas nem em seus adros, nem se cantem cantigas desonestas ou coisas semelhantes. Porém não é nossa tentação proibir que no adro se possam fazer representações ao divino, sendo aprovadas por Nós ou por nosso provisor; nem que outrossim, na ocasião de festas, entrem danças e folias nas Igrejas, sendo honestas e decentes, enquanto se não disser missa nem se celebrem os ofícios divinos (VIDE, 2010, p. 411-412).

É possível afirmar, em um contexto geral, que essa citação do arcebispo que poderia ter sido facilmente escrita por Nina Rodrigues. De fato, quando atentamos às descrições feitas por Nina Rodrigues da Festa ao Nosso Senhor do Bonfim, é possível conjecturar que Monteiro da Vide era mais tolerante às práticas não institucionais católicas do que Nina Rodrigues. 
A lavagem na quinta-feira era uma verdadeira bacchanal num templo christão! Negros aguadeiros e mulheres com potes d'agua e vassouras em grande alarido de sambas e vivas entravam pela igreja com o fim de lavai-a e os cantos obscenos, os lundús e a bebedeira reinavam sem respeito ao lugar, sendo toda a scena representada por homens e mulheres semi-nuas e embriagadas! Terminavam sempre com disturbios, pancadaria, ciumadas, ferimentos e até, quando esquentavam-se os animos, davam-se casos de morte. Felizmente o poder com petente tem prohibido similhante festa (RODRIGUES, 1935, p. 181).

Rodrigues observou que a proibição teria se limitado à festa do Bomfim e não abrangido a lavagem no dois de fevereiro de Santo Amaro, na festa de N. Senhora das Candeias, na qual o símile africano manter-se-ia inalterável. Diferente das associações de Oxalá, menos constantes e claras seriam as equivalências das diversas invocações da Virgem Maria. Algumas mães de terreiro diziam corresponder a Oxum e outras à Iemanjá, explica Nina Rodrigues. Outra correspondência de difícil compreensão para Rodrigues seria entre Ogum e Santo Antônio. Em relação à equivalência dos deuses, Rodrigues explica:

Mas o ponto capital deste estudo é que a esta equivalencia das divindades corresponde a mais completa harmonia de sentimentos religiosos, na adoração prestada aos deuses dos dois cultos. E é precisamente este facto que dá a ilusão da con versão catholica dos negros. Sem renunciar aos seus deuses ou Orisás, o negro bahiano tem, pelos santos catholicos, profunda devoção levada até ao sacrificio e ao fanatismo. Mas esse sacrificio e esse fanatismo não podem ser sinão essencialmente fetichistas; os santos catholicos e até mesmo as invocações do filho de Deus constituem para os negros outras tantos orisás (RODRIGUES, 1935, p. 182).
Haveria, desse modo, a ideia de uma pseudoconversão, pois, segundo Nina Rodrigues, os negros tomariam os santos cristãos como se esses fossem orixás:

A mãe de terreiro, Linvaldina, é devotada ao mesmo tempo a Nossa Senhora da Conceição e a Ogun. O proprietário do engenho onde ella reside, admirado de eu lhe dizer que ella era ali a mãi de terreiro, me affirmava que esta negra faz grandes despesas com a festa catholica da Virgem Maria. No dia de Natal, assisti-a interromper pela madrugada o candomblé que dirigia e em que se festejava Obatalá para ir ouvir a missa do gallo. Interpellei-a sobre o modo por que conseguia harmonizar as suas crenças catholica e fetichista fazendo-lhe ver que não podia haver conciliação possivel entre os dois cultos, pois os padres christãos não admittem a existencia das suas divindades e chamam de infieis aos que adoram pedras, idolos, etc. Ella respondeu-me que os padres não conhecem os deuses da Costa, mas que ella tem provas materiaes de que elles existem e são tão verdadeiros como os santos dos brancos. Nada tem e que ver, porém, com a irreconciliação dos santos das duas crenças, pois não somos obrigados a esposar as dissensões dos nossos amigos, e me perguntava si pelo facto de dois amigos meus se desavirem eu havia de tomar o partido de um delles contra o outro (RODRIGUES, 1935, p. 182-183).

É nítido o esforço metodológico de Nina Rodrigues em sistematizar esses processos do qual é testemunha, tentar traduzir em palavras, termos e conceitos, uma prática cotidiana de uma sociedade, proporcionando um paradigma explicativo a questões e princípios tão distantes de sua prática profissional, mais que isso, o esforço epistemológico de entender e explicar o outro, o diferente de si. Nesse esforço compreensivo, relata encontrar misturados, com frequência, símbolos cristãos e fetichistas 
[...] juntamente com os outros gris-gris ou talismans fetichistas se encontram por toda a parte pequenas cruzes de madeira, que ao lado das figas, búzios, etc., figuram nas cestas das compradeiras, nos taboleiros das vendedeiras ambulantes, nas vendas, etc (RODRIGUES, 1935, p. 185).

O autor salienta que tais práticas não se limitariam apenas aos negros ditos "boçais e ignorantes":

O numero de brancos, mulatos e indivíduos de todas as cores e matizes que vão consultar os negros feiticeiros nas suas aflições, nas suas desgraças, nos que crêem publicamente no poder sobrenatural dos talismans e feitiços, dos que em muito maior numero, zombam deles em publico, mas occultamente os ouvem, os consultam, esse numero seria incalculável se não fosse mais simples dizer de um modo geral que é a população em massa, a excepção de uma pequena minoria de espíritos superiores e esclarecidos que tem a noção verdadeira do valor exacto dessas manifestações psycologicas. É que no Brazil o mestiçamento não é só physico e intellectual, é ainda affectivo ou dos sentimentos, religioso igualmente portanto (1935, p. 186).

Embora não aprofunde, Rodrigues acrescenta que não era apenas o catolicismo que recebia influências fetichistas, mas também as práticas espíritas e a cartomancia. Rodrigues explica que do mesmo modo que a histeria no negro, as manifestações mais francas da nevrose constituem o fundo do pretenso espiritismo da cabocla. Mas, o que há de curioso é que, os mesmos médios serviriam nos candomblés, para as manifestações dos santos africanos ou orixás, o que corroboraria a opinião de que os estados de santo dos africanos no Brasil não seriam mais do que manifestações do somnambulismo hysteri- co. Para uma publicação anterior na Revista Brasileira, Nina Rodrigues havia denominado o capítulo de "O animismo fetichista dos negros bahianos", o qual trata da conversão dos negros como "Ilusões da catequese no Brazil", por entender que:

Continuar a affirmar em face de todos os documentos, que os negros bahianos são catholicos e que tem êxito no Brazil a tentativa de conversão é portanto, alimentar uma illusão que póde ser cara aos bons intuitos de quem tinha interesse de que as coisas tivessem passado assim, mas que certamente não está conforme a realidade dos factos (RODRIGUES, 1935, p. 199).

O fato é que as preocupações quanto a feitiçarias, superstições, sortes, agouros, artes mágicas, pacto com o demônio, uso de feitiçarias, cartas de tocar, palavras, bebidas amatórias ou coisas semelhantes, que estão presentes em Nina Rodrigues por denunciarem a baixa evolução mental da sociedade baiana do século XIX, já faziam parte das preocupações da Igreja Católica desde o século XVIII, especialmente no que concerne ao caso específico da Bahia, por meio das Constituições formuladas por Monteiro da Vide. ${ }^{4}$

Nina Rodrigues não faz menção direta às Constituições, mas há de se concordar que as normas, orientações e visões são componentes da realidade social em que ele se propõe a pensar, questionar, ressiginificar, e consequentemente representar (CHARTIER, 2002). As categorias que estruturavam seu campo de análise eram exatamente aquelas cuja história fazia parte, o produto de divisões móveis e temporárias, tanto que se propõe a distinguir, ainda que de forma muito inicial, o que seria religião na África e no Brasil. 
Assim, a radical divisão entre produção e consumo leva a postular que as ideias ou formas têm um sentido intrínseco, totalmente independente de sua apropriação por um sujeito ou por um grupo de sujeitos. Fazer como se os textos tivessem significações dadas por si mesmo, independente das leituras que os constroem, leva a relacioná-los ao campo intelectual do historiador que os analisa, portanto, a decifrá-los por meio de categorias de pensamento, cuja historicidade não é percebida e se dá implicitamente por pensamentos. Destituir essa historicidade exige que o "consumo" cultural ou intelectual seja tomado como uma produção, que certamente não fabrica objeto nenhum, mas constitui representações que nunca são idênticas àquelas que o produtor, o autor ou o artista investiram em sua obra.

Embora não se possa dizer categoricamente que Rodrigues parta do objetivo de defesa da fé católica, suas observações, interpretações e conclusões para pensar religião não poderiam sustentar como insignificante a diferença entre os quadros de referência, em função dos quais uma sociedade organiza as ações e os pensamentos (CERTEAU, 1982). Embora parta da ciência e de um Estado laico, não consegue simplesmente apagar de sua "visão de mundo" todo um aparato católico de formação, de percepção de valores, próprio do lugar social no qual ele se insere.

Na forma como é apresentada nos escritos de Nina Rodrigues, a hierarquia religiosa no Brasil surge como claramente diferenciada. Em seu topo, estaria a mais elevada, mas extremamente tênue religião: o monoteísmo católico. Seguida, espessa e largamente, da idolatria e mitologia católica dos santos profissionais, que abrangeria a massa da população; abaixo dessa, estaria como síntese do animismo superior do negro, a mitologia jeje-iorubana, caracterizada pela equivalência dos orixás africanos com os santos católicos. E no estágio ainda mais baixo viria o fetichismo estreito e inconvertido dos africanos das tribos mais atrasadas, dos índios, dos negros crioulos e dos mestiços do mesmo nível intelectual. Vê-se, portanto, que o pensar o "outro" sempre parte de um "eu", no caso de Nina Rodrigues e do estudo das religiões africanas, de um "eu católico" a partir do qual classificaria as demais organizações religiosas e seu grau de civilização. Isso ocorre tanto por conta da formação católica de Nina Rodrigues, quanto pela tradição religiosa católica no Brasil, uma vez que para alçar os candomblés à condição de religião, era preciso identificá-los como um culto organizado nos moldes próximos do catolicismo, ou seja, por meio de uma teologia, liturgia, concepção de pós-morte, crença numa divindade superior e assim por diante.

A "formalidade das práticas" de Certeau (1982) auxilia a compreensão desse processo, elas referem-se ao reemprego de determinadas estruturas em função de uma ordem que elas não mais determinam. Ainda que intactas, as condutas - por exemplo - inscrevem-se em outras trajetórias sociais, obedecem a critérios, classificam-se segundo categorias, visam objetivos que mudam. Essa formalidade está mais ou menos de acordo com os discursos oficiais ou teóricos; ela os questiona já que organiza também uma prática da leitura ou da audição, isto é, 
uma prática desses discursos, sem falar das práticas que eles esquecem ou exilam. Considerando a necessidade em medir a distância, ou as relações, entre a formalidade das práticas e a das representações; por aí pode-se analisar, com as tensões que trabalham uma sociedade na sua espessura, a natureza e as formas de sua mobilidade. É exatamente o que se opera no Brasil, mediante separação Estado/Igreja, embora essa já não determine mais aquele, ainda exerce enorme influência sobre ele.

Conforme indicou Paula Montero (2006), no Brasil, o universo jurídico-legal definiu o religioso em referência ao Católico. A autora corrobora a indicativa de Nina Rodrigues ao tratar da "ilusão da catequese", devoção e conversão, que teriam orientado grande parte das análises sobre os fenômenos religiosos, descrevendo com precisão o que ocorreria no Brasil no campo das práticas. Dessa maneira, embora tenha perdido legitimidade para organizar o mundo público, a Igreja Católica foi importante matriz no processo de constituição da esfera pública no Brasil. Ela não deixa de ser Igreja depois da República: ainda hoje é legitimada como responsável pelos ritos civis socialmente válidos. Assim, embora a oposição entre crença e superstição não possa servir de fundamento para o controle das práticas rituais não católicas, a distinção entre sacramento e rito ainda é reconhecida como perfeitamente legítima. Na medida em que estão na base da formação da esfera pública, alguns códigos católicos ainda são percebidos como aqueles aceitáveis para expressar ou demandar algo no espaço público. Ain$\mathrm{da}$, reverberam na ideia de bem comum, nas associações entre religião e verdade, de um lado, e entre feitiçaria e falsidade, de outro (MONTERO, 2006).

Ao produzir um paradigma para o estudo das religiões africanas, Nina Rodrigues o partiu de um olhar católico. Apesar de médico, a estruturação do discurso assume um caráter predominantemente etnológico/ antropológico de cunho católico. Certeau (1982) explica que o pesquisador crente não pode fazer mais do que introduzir sub-repticiamente convicções subjetivas no seu estudo científico. Tais motivações intervêm na escolha do objeto (relativo a um interesse religioso) ou na finalidade do estudo (em função de preocupações presentes, por exemplo: a descristianização e suas origens, a realidade de um cristianismo popular, etc.).

As "marcas" encontradas em ambos os discursos articulam a apropriação de uma metodologia de referencial protestante para representar religiões africanas por meio de uma ressignificação católica. Por "marcas", entende-se uma combinação objetiva entre uma prática e um signo, um ponto de interseção entre a linguagem da sociedade e a enunciação de uma fé. A "marca" focaliza a expressão religiosa em gestos particulares. É inexato pensar essas formalidades como "religiosas", já que, precisamente, elas deixam de sê-lo, e que, num certo sentido, se poderia considerar o tempo de seu "preenchimento" religioso como um momento da história dessas formas culturais. Geralmente, toda sociedade nascida e surgida de um universo religioso deve enfrentar a relação que mantém com sua arqueologia. Esse problema está inscrito na cultura presente pelo fato das estruturas religiosas serem desloca- 
das dos conteúdos religiosos que organizam as condutas racionais (CERTEAU, 1982).

Certeau (1982) indica que "uma sociedade inteira diz o que está construindo, com as representações do que está perdendo. $\mathrm{O}$ sagrado se torna a alegoria de uma cultura nova, no momento em que, inversamente, as aventuras do corpo fornecem à experiência espiritual sua nova linguagem" (1982, p. 140). Ocorre, assim, uma retomada das estruturas religiosas, mas em outro regime. As organizações cristãs são reempregadas em função de uma ordem que elas não mais determinam: para as religiões africanas e a ciência. Mesmo intactas nelas mesmas, as condutas inscrevem-se em outras trajetórias sociais. Obedecem a critérios, classificam-se segundo categorias, visam a objetivos que podem mudar. Essas questões revelam uma formalidade das práticas, ou seja, a presença de um discurso católico em discurso pretensamente médico-científico, o de Nina Rodrigues sobre as religiões afro-brasileiras.

\section{Abstract}

The aim is to understand the interpretations drawn on Bahia religiosity taking as historical sources the works $O$ animismo fetichista dos negros bahianos (1935) and Os africanos no Brasil (1982), written by Nina Rodrigues; and Constituições Primeiras do Arcebispado da Bahia, written by archbishop Sebastião Monteiro da Vide, promulgated in 1777. More specifically, to realize how this could have contributed to development of the notion of "illusion of catechesis" used by Nina Rodrigues to produce knowledge about the religiosity african-Brazilian, in Bahia (Nineteenth century). The theoretical framework are Michel de Certeau (1982) to think about belief's anthropology and Catholic " practices' formalities", and Roger Chartier $(1990,2002)$ and the concepts of "world view" and "representation".

Keywords: Illusion of Catechesis. Nina Rodrigues. Bahia religiosity.

\section{Resumen}

El objetivo es comprender las interpretaciones desarrolladas acerca dela religiosidad de Bahía tomando como fuentes históricas las obras $O$ animismo fetichista dos negros bahianos (1935) y Os africanos no Brasil (1982), de Nina Rodrigues; y las Constituições Primeiras do Arcebispado da Bahia, escrito por el Arzobispo Sebastian Monteiro da Vide, promulgadas en 1777. Entender más específicamente cómo esto podría haber contribuido al desarrollo de la noción de "ilusión de la catequesis" presente en Nina Rodrigues para producir conocimiento sobre la religiosidad afro-brasileño de Bahía en el siglo XIX. El marco teórico utilizado consiste en Michel de Certeau (1982) para pensar la antropología de la creencia y "formalidades de las prácticas" católicas y Roger Chartier $(1990,2002)$ y los conceptos de "visión del mundo" y "representación".

Palabras clave: Ilusión de la catequesis. Nina Rodrigues. Religiones afro-brasileñas. 


\section{Notas}

1 Vale destacar que, em caminho inverso, e preocupada com o discurso dos intelectuais católicos do século XX, Solange Ramos de Andrade (2012), no artigo intitulado "Intelectuais Católicos e a Ilusão da Catequese no Brasil", problematizou o processo de construção do discurso sobre a identidade religiosa no Brasil, a partir da influência dos intelectuais, iniciando com a obra de Nina Rodrigues, em fins do século XIX, fornecendo as que forneceu as primeiras descrições acerca das manifestações religiosas africanas e as relações com as crenças de cunho católico que o escravo encontrou e assimilou, até os principais autores da década de 1960, como Thales de Azevedo.

2 Tais aspectos foram aprofundados e podem ser consultados em minha tese de doutorado Nina Rodrigues $e$ as religiões afro-brasileiras: a "formalidade das práticas" católicas no estudo comparado das religiões (Bahia - século XIX). Nessa, pude compreender a investigação realizada por Nina Rodrigues acerca das manifestações religiosas dos povos africanos e seus descendentes na Bahia do século XIX. A tese que se demonstrou é a de que, ao torná-las objeto de ciência e buscar formas conceituais para referenciá-las, Nina Rodrigues representou-as a partir de um referencial cristão: o monoteísmo católico. Para tanto, adotei um duplo percurso: inicialmente, travei um diálogo entre as representações do sujeito histórico Nina Rodrigues formuladas pela bibliografia especializada, buscando apontar uma nova forma de abordagem que se afastasse de uma história cujos personagens sejam enquadrados enquanto heróis ou vilões; para, em seguida, analisar as obras de Nina Rodrigues, atentando à forma como ele se apropriou do modelo evolucionista cultural de E. B. Tylor para representar as religiões dos afrodescendentes no Brasil; tendo por consequência desenvolvido um paradigma para pensar as religiões no Brasil, pautado no método de estudo comparado, cujo principal referente consistiu no monoteísmo católico. Embora não se possa dizer categoricamente que Nina Rodrigues parta do objetivo de defesa da fé católica, a pesquisa constatou que suas observações, interpretações e conclusões para pensar religião não poderiam sustentar como insignificante a diferença entre os quadros de referência em função, dos quais uma sociedade organiza as ações e os pensamentos. Embora parta da ciência e de um Estado laico, não se consegue, como pretendia, simplesmente apagar de sua "visão de mundo" todo um apara- to católico de formação, de percepção de valores, próprio do lugar social no qual ele se insere.

3 A fim de referenciar as Constituições Primeiras do Arcebispado da Bahia, optou-se seguir o modelo da ficha catalográfica da edição utilizada: VIDE, Sebastião Monteiro da. Constituições Primeiras do Arcebispado da Bahia: estudo introdutório. Edição de Bruno Fleiter, Evergton Sales Souza, Istvan Jancsó, Pedro Putoni (Orgs.). São Paulo: EDUSP, 2010.

4 “Título 3. Das feitiçarias, superstições, sortes e agouros. Como serão castigados os que usarem de artes mágicas" (VIDE, 2010, p. 462); “Título 4. Que nenhuma pessoa tenha pacto com o demônio nem use de feitiçarias; e das penas que incorrem os que o fizerem" (VIDE, 2010, p. 463) e "Título 5. Das penas dos que usam cartas de tocar, e de palavras ou bebidas amatórias ou coisas semelhantes" (VIDE, 2010, p. 464).

\section{Referências}

ANDRADE, Solange Ramos de Andrade. Intelectuais católicos e a ilusão da catequese no Brasil. Revista Brasileira de História das Religiões. ANPUH, Ano V, n. 14, set. 2012, p. 225239 - ISSN 1983-2850. Disponível em: <http:/ / www.dhi.uem.br/gtreligiao/index.html>. Acesso em: 21 set. 2013.

CERTEAU, Michel de. A Escrita da história. Rio de Janeiro: Forense Universitária, 1982.

CHARTIER, Roger. À beira da falésia: a história entre incertezas e inquietudes. Trad. Patrícia Chittoni Ramos. Porto Alegre: Ed. Universidade/UFRGS, 2002.

. A história cultural: entre práticas e representações. Tradução de Maria Manuela Galhardo. Rio de Janeiro: Bertrand Brasil, 1990.

FLEITER, Bruno et al. Estudo introdutório. In: _ (Orgs.). Constituições primeiras do arcebispado da Bahia. São Paulo: EDUSP, 2010. p. 7-104.

MONTERO, Paula. Religião, pluralismo e esfera pública no Brasil. Novos Estudos - CEBRAP, São Paulo, n. 74, p. 47-65, Cebrap, mar. 2006. 
RODRIGUES, Nina. O animismo fetichista dos negros bahianos. Rio de Janeiro: Civilização Brasileira, 1935.

Os africanos no Brasil. 6. ed. São Paulo: Ed. Nacional; Brasília: Ed. Universidade de Brasília, 1982.

SERAFIM, Vanda Fortuna. Nina Rodrigues $e$ as religiões afro-brasileiras: a "formalidade das práticas" católicas no estudo comparado das religiões (Bahia - século XIX). 2013. Tese (Doutorado em História) - Universidade Federal de Santa Catarina, Centro de Filosofia e Ciências Humanas. Programa de Pós-graduação em História. Florianópolis, 2013.

VIDE, Sebastião Monteiro da. Constituições primeiras do arcebispado da Bahia. In: FLEITER, Bruno et al. (Orgs.). Estudo introdutório.

São Paulo: EDUSP, 2010. 